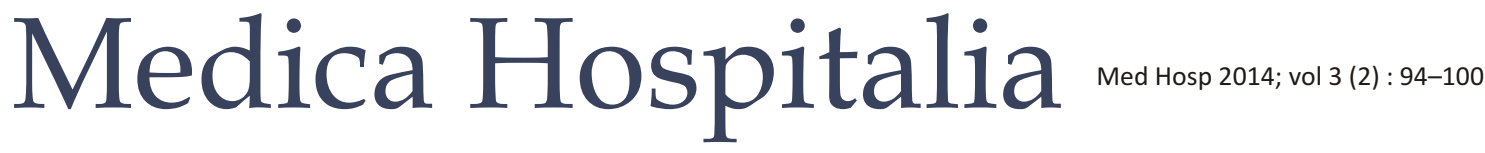

Original Article

\section{Pengaruh Pemberian Metilprednisolon Oral Terhadap Perubahan Kadar C-Reactive Protein Penderita Kanker Kepala Leher yang Diberikan Radioterapi}

\author{
Hesti Dyah Palupi*, Muyassaroh**, Dwi Antono** \\ *Departemen IK THT-KL Fakultas Kedokteran Universitas Diponegoro Semarang / RSUP Dr. Kariadi Semarang
}

\begin{abstract}
Abstrak
Latar belakang : Radioterapi dapat memberikan efek inflamasi terus menerus pada kanker kepala leher (KKL). C-reactive protein (CRP) merupakan protein fase akut sebagai parameter status inflamasi terkini. Metilprednisolon bekerja pada efektor akhir untuk menginhibisi inflamasi. Penelitian ini bertujuan untuk mengetahui pengaruh pengaruh pemberian metilprednisolon terhadap kadar CRP pada penderita KKL yang mendapat radioterapi.

Metode : Penelitian intervensi yang membandingkan perubahan kadar CRP pasien KKL dengan radioterapi antara kelompok yang diberikan metilprednisolon ( $n=15)$ dan yang tidak diberikan metilprednisolon ( $n=15$ ) pada sebelum, 7 kali radioterapi dan 14 kali radioterapi.

Hasil : Hasil penelitian didapatkan peningkatan bermakna kadar CRP pada kelompok metilprednisolon dan kontrol setelah 7 kali radioterapi $(p<0,05)$. Perbedaan bermakna perubahan kadar CRP antara kelompok metilprednisolon dan kontrol setelah 14 kali radioterapi $(p<0,05)$.

Simpulan : Pemberian metilprednisolon dapat mempengaruhi perubahan kadar CRP pasien KKL yang diberikan radioterapi.
\end{abstract}

Kata kunci : c-reactive protein, radioterapi, kanker kepala leher

\section{The effect of oral methylprednisolon administration to the C-Reactive protein level on the radiotherapy treatment for head neck cancer patients}

\section{Abstract}

Background : Radiotherapy can provide continuous inflammatory effects in head and neck cancer. C-reactive protein (CRP) is an acute phase proteins as parameters of inflammatory status. Methylprednisolone work at the end effector to inhibit inflammation. This study was aimed to investigate the effect of methylprednisolone on CRP levels in patients head and neck cancer who recerived radiotherapy.

Methods : Intervensional study that comparing the changes on CRP levels between head and neck cancer patients were given methylprednisolon group $(n=15)$ and were not given methylprednisolone $(n=15)$ at before, after 7 times and 14 times radiotherapy. Data analysis using differentiation test.

Results : The results showed a sgnificant increasement on CRP levels in the methylprednisolone and control group at 7 times radiotherapy $(p<0,05)$. Significant differences on CRP levels changing between methylprednisolone and control group at 14 times radiotherapy $(p<0,05)$.

Conclusion : Methylprednisolone may affect CRP levels head and neck cancer patients with radiotherapy.

Keywords : c-reactive protein, radiotherapy, head and neck cancer

\section{PENDAHULUAN}

Radioterapi merupakan pilihan pengobatan yang efektif untuk Keganasan Kepala Leher (KKL). Radiasi memberikan efek inflamasi secara terus-menerus oleh mediator-mediator inflamasi. Selama radioterapi, beberapa jenis protein (protein fase akut) diproduksi akibat adanya inflamasi dan stress oksidasi. Protein ini termasuk di antaranya adalah CRP, feritrin dan ceruloplasmin. ${ }^{7}$ CRP diregulasi oleh sitokin proinflamasi seperti interleukin (IL)-1, tumor necrotic factor (TNF) $a$, dan terutama IL-6. Konsentrasi CRP merupakan yang pertama meningkat dalam hitungan jam dari respon inflamasi dan meningkat hingga beberapa ribu kali lipat. CRP memiliki mobilitas yang cepat sehingga dapat dijadikan parameter terhadap status inflamasi terkini. Hal ini berkaitan dengan sitokin dan peran fungsionalnya terhadap inflamasi aktif. ${ }^{8}$ 
Penelitian Fazilat et al dan Koc et al telah melaporkan peningkatan kadar protein fase akut, diantaranya CRP dan albumin pada penderita selama diberikan radioterapi. Didapatkan peningkatan kadar CRP pada pertengahan siklus dan akhir siklus radioterapi. ${ }^{3,4}$

Metilprednisolon merupakan suatu antiinflamasi golongan glukokortikoid. Metilpredisolon bekerja sebagai efektor akhir pada aksis adrenal-pituitarihipotalamus untuk menginhibisi inflamasi. Mediator yang dihambat di antaranya TNFa, IL-1, IL-6 dan prostaglandin. ${ }^{13}$ Penelitian oleh Meduri et al menunjukkan bahwa pemberian metilprednisolon injeksi menurunkan kadar CRP pada pasien Acute Respiratory Distress Syndrome (ARDS) dan memberikan perbaikan signifikan pada disfungsi paru serta waktu sakit pasien. ${ }^{6}$ Tujuan penelitian ini adalah mengetahui pengaruh pemberian metilprednisolon terhadap kadar CRP pada penderita KKL yang mendapat radioterapi.

\section{METODE}

Penelitian ini merupakan penelitian intervensi yang dilakukan di RSUP Dr. Kariadi Semarang pada bulan April-Juli 2014. Jumlah sampel yang ditentukan adalah 15 tiap kelompok. Peneliti membandingkan kadar CRP pada kelompok metilprednisolon $(n=15)$ dan kontrol $(n=15)$ pada saat sebelum radioterapi, 7 kali radioterapi dan 14 kali radioterapi. Seluruh subyek sampel memenuhi kriteria inklusi dimana merupakan penderita KKL stadium 3 dan 4 yang mendapat radioterapi dengan rentang usia 15-60 tahun, skala Karnofsky $>60 \%$ dan bersedia untuk ikut penelitian. Subyek sampel yang menderita penyakit infeksi, kronik seperti paru dan jantung, sistemik seperti diabetes dan hipertensi serta gastritis akan dieklusi dari penelitian. Alat dan bahan menggunakan rekam medis dan metilprednisolon tablet 16mg. Pemberian metilprednisolon sekali sehari dilakukan pada kelompok metilprednisolon setelah kedua kelompok mendapat 7 kali radioterapi.

Uji normalitas data menggunakan uji Shapiro-Wilk $(n<50)$. Uji beda berpasangan Wilcoxon sign ranked test dilakukan untuk melihat perubahan kadar CRP antara sebelum, 7 kali radioterapi dan 14 kali radioterapi pada masing-masing kelompok metilprednisolon dan kontrol. Uji beda tidak berpasangan Mann-Whitney $U$ test dilakukan untuk membandingkan perubahan kadar CRP antara kelompok metilprednisolon dan kontrol. Ethical clearance diperoleh dari Komisi Etik Penelitian Kesehatan FK Undip/ RSUP Dr. Kariadi Semarang dan sebelum dilakukan penelitian dimintakan ijin kepada orang tua responden melalui informed consent.

\section{HASIL}

\section{Karakteristik Subyek Penelitian}

Didapatkan 30 subyek, terdiri dari 15 subyek pada kelompok penderita KKL yang mendapat radioterapi dan tablet metilprednisolon dan 15 subyek kelompok penderita KKL yang mendapat radioterapi tanpa pemberian tablet metilprednisolon.

Hasil penelitian didapatkan laki-laki 22 (73,33\%) dan perempuan $8(26,7 \%)$. Distribusi jenis kelamin pada kedua kelompok homogen $(p=0,409)$. Lokasi tumor terbanyak adalah nasofaring $19(63,3 \%)$ dan paling sedikit adalah laring $3(10 \%)$. Stadium tumor pada penelitian ini terbanyak adalah stadium 4 sebesar 16 $(53,3 \%)$ dan stadium 3 sebesar 14 (46,7\%) subyek. Distribusi stadium tumor pada kedua kelompok homogen $(p=0,642)$ (Tabel 5.1). Derajat mukositis sebelum ER kelompok metilprednisolon dan kontrol didapatkan sama besar yaitu grade 0 sebanyak 13 subyek $(86,67 \%)$ dan grade 1 sebanyak 2 subyek (13,33\%). Derajat mukositis setelah 7 kali radioterapi kelompok metilprednisolon didapatkan grade 1 sebanyak 14 subyek $(93,3 \%)$ dan grade 2 sebanyak 1 subyek $(6,67 \%)$ sedangkan pada kelompok kontrol didapatkan grade 1 sebanyak 15 subyek (100\%). Derajat mukositis setelah 14 kali radioterapi pada kelompok metilprednisolon didapatkan grade 0 sebanyak 2 subyek $(13,33 \%)$, grade 1 sebanyak 13 subyek (86,67\%) dan tidak didapatkan mukositis pada grade 2 sedangkan pada kelompok kontrol didapatkan grade 1 sebanyak 6 subyek (60\%) dan grade 2 sebanyak 9 subyek (60\%). Hasil analisis didapatkan bahwa derajat mukositis pada kelompok metilprednisolon dan kontrol sebelum radioterapi dan setelah 7 kali radioterapi terdistribusi homogen $(p=1)$, sedangkan pada kelompok setelah 14 kali radioterapi didapatkan hasil berbeda signifikan antara kelompok metilprednisolon dan kontrol $(p<0,05)$.

\section{Kelompok Metilprednisolon}

Kadar CRP pada kelompok metilprednisolon didapatkan meningkat baik pada penilaian sebelum dan setelah $7 \mathrm{kali}$ radioterapi. Perubahan kadar CRP didapatkan pada kelompok pasien dengan 14 kali radioterapi dan tablet metil prednisolon oral. Peningkatan CRP pada kelompok sebelum radioterapi dengan mean $0,41 \pm 0,59$ sedangkan pada kelompok 7 kali radioterapi terdapat peningkatan CRP dengan mean 1,18 $\pm 1,51$. Pada kelompok 14 kali radioterapi juga terdapat peningkatan kadar CRP dengan mean 1,60 2,37 .

Data kelompok metilprednisolon didapatkan tidak normal, walaupun setelah dilakukan transformasi data. Analisis data dilanjutkan dengan test non parametrik Wilcoxon Signed Ranks Test, didapatkan peningkatan bermakna kadar CRP antara kelompok sebelum dan 7 kali radioterapi dengan $p<0,05(p=0,001)$. 


\begin{tabular}{|c|c|c|c|c|}
\hline Variabel & $\begin{array}{l}\text { Metilprednisolon (\%) } \\
\qquad(n=15)\end{array}$ & $\begin{array}{c}\text { Kontrol (\%) } \\
(n=15)\end{array}$ & $\begin{array}{l}\text { Total (\%) } \\
(n=30)\end{array}$ & $p^{*}$ \\
\hline Usia (th) & & & & 0,706 \\
\hline \multicolumn{5}{|l|}{ Kelompok usia (th) } \\
\hline $21-30$ & $2(6,7)$ & $2(6,7)$ & $4(13,3)$ & \\
\hline $31-40$ & $1(3,3)$ & $3(10)$ & $4(13,3)$ & \\
\hline $41-50$ & $6(20)$ & $4(5)$ & $10(33,3)$ & \\
\hline $51-60$ & $6(20)$ & $6(20)$ & $12(40)$ & \\
\hline \multicolumn{5}{|l|}{ Jenis kelamin } \\
\hline Laki-laki & $10(33,3)$ & $12(40)$ & $22(73,3)$ & 0,409 \\
\hline Perempuan & $5(16,7)$ & $3(10)$ & $8(26,7)$ & \\
\hline \multicolumn{5}{|l|}{ Lokasi tumor } \\
\hline Nasofaring & $7(23,3)$ & $12(40)$ & $19(63,3)$ & 0,084 \\
\hline Orofaring & $3(10)$ & $1(3,33)$ & $4(13,3)$ & \\
\hline Sinus paranasal & $4(13,3)$ & $0(0)$ & $4(13,3)$ & \\
\hline Laring & $1(3,3)$ & $2(6,7)$ & $3(10)$ & \\
\hline \multicolumn{5}{|l|}{ Stadium tumor } \\
\hline Stadium 3 & $7(23,3)$ & $7(23,3)$ & $14(46,6)$ & 0,642 \\
\hline Stadium 4 & $8(26,7)$ & $8(26,7)$ & $16(53,3)$ & \\
\hline \multicolumn{5}{|l|}{ Derajat mukositis } \\
\hline \multicolumn{5}{|l|}{ Sebelum radioterapi } \\
\hline Grade 0 & $13(86,7)$ & $13(86,7)$ & $26(86,7)$ & 1,000 \\
\hline Grade 1 & $2(13,3)$ & $2(13,3)$ & $4(13,3)$ & \\
\hline \multicolumn{5}{|l|}{7 kali radioterapi } \\
\hline Grade 1 & $14(93,3)$ & $15(100)$ & $29(96,67)$ & 1,000 \\
\hline Grade 2 & $1(6,7)$ & 0 & $1(3,33)$ & \\
\hline \multicolumn{5}{|l|}{14 kali radioterapi } \\
\hline Grade 0 & $2(13,3)$ & 0 & $2(6,67)$ & $0,001 *$ \\
\hline Grade 1 & $13(86,7)$ & $6(40)$ & $19(63,3)$ & \\
\hline Grade 2 & 0 & $9(60)$ & $9(30)$ & \\
\hline
\end{tabular}

Peningkatan kadar CRP didapatkan antara kelompok 7 kali dan 14 kali radioterapi namun tidak bermakna dengan $p>0,05 \quad(p=0,379)$. Kadar CRP mengalami peningkatan bermakna antara kelompok sebelum dan setelah 14 kali radioterapi dengan $p<0.05(p=0,006)$.

\section{Kelompok Kontrol}

Kadar CRP pada kelompok kontrol didapatkan peningkatan baik pada penilaian sebelum, 7 kali dan 14 kali radioterapi. Peningkatan CRP pada kelompok sebelum radioterapi dengan mean 1,08 \pm SD 1,11, sedangkan pada kelompok 7 kali radioterapi didapatkan peningkatan dengan mean 2,20 \pm SD 1,73 dan pada kelompok 14 kali radioterapi didapatkan peningkatan dengan nilai mean 4,05 $\pm 4,55$. Sebaran data didapatkan tidak normal, setelah transformasi data tetap tidak normal. Analisis data dilanjutkan dengan test non parametrik Wilcoxon Signed Ranks Test, didapatkan peningkatan bermakna kadar CRP antara kelompok sebelum dan 7 kali radioterapi dengan $p<0,05(p=0,001)$. Peningkatan bermakna kadar CRP didapatkan antara kelompok 7 kali dan 14 kali radioterapi dengan $p<0,05$ $(p=0,001)$. Kadar CRP meningkat bermakna antara kelompok sebelum dan 14 kali radioterapi dengan $p<0,05$ $(p=0,001)$. 


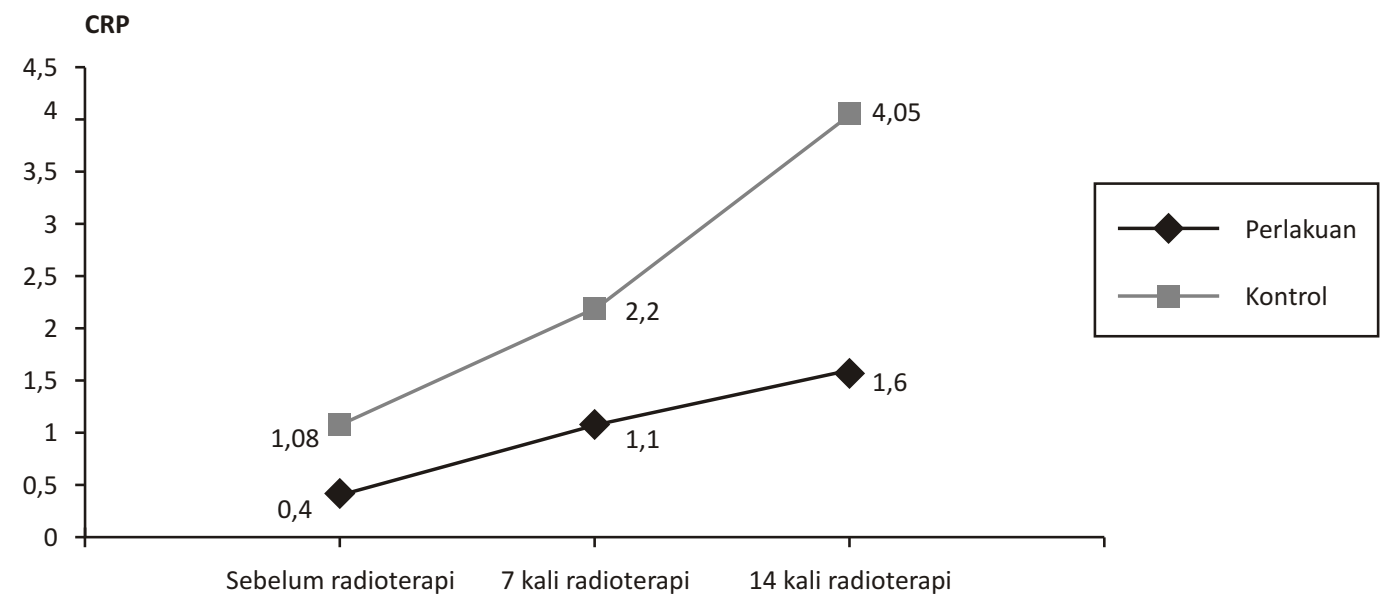

Gambar 1. Perubahan kadar Creactive protein (CRP) selama radioterapi.

TABEL 2

Non parametric Mann-Whitney Test perubahan kadar CRP kelompok metilprednisolon dan kontrol (I; sebelum, II; 7 kali, III; 14 kali radioterapi)

\begin{tabular}{lccc} 
Variabel (mean) & Metilprednisolon & Kontrol & $\boldsymbol{p}$ \\
\hline Delta CRP I-II & 0,76 & 1,05 & 0,089 \\
Delta CRP II-III & 0,11 & 1,85 & 0,000 \\
Delta CRP I-III & 1,18 & 2,97 & 0,008 \\
\hline
\end{tabular}

\section{Uji Komparatif Perubahan Kadar CRP Kelompok Metilprednisolon dan Kontrol}

Delta CRP kelompok metilprednisolon antara kelompok sebelum dan 7 kali radioterapi dengan mean 0,76 dan kelompok kontrol dengan mean 1,05. Analisis menggunakan non parametric Mann-Whitney test didapatkan peningkatan kadar CRP tidak berbeda bermakna antara kedua kelompok metilprednisolon dan kontrol dengan $p>0,05(p=0,089)$. Delta CRP 7 kali dan 14 kali radioterapi pada kelompok metilprednisolon didapatkan mean 0,11 dan kelompok kontrol 1,85. Hasil analisis didapatkan penurunan kadar CRP antara kelompok metilprednisolon dan kontrol berbeda signifikan dengan $p<0.05(p=0.00)$. Delta CRP kelompok sebelum radioterapi dan setelah 14 kali radioterapi pada kelompok metilprednisolon didapatkan mean 1,18 dan kelompok kontrol 2,97. Analisis komparatif non parametrik antara kelompok metilprednisolon dan kontrol didapatkan delta CRP berbeda signifikan dengan $p<0.05(p=0,008)$.

\section{PEMBAHASAN}

\section{Karakteristik Subyek Penelitian}

Hasil penelitian menunjukkan bahwa subyek usia termuda 20 tahun dan tertua 60 tahun. Hasil ini sesuai dengan literatur yang menyatakan bahwa prevalensi keganasan paling banyak pada kelompok usia lebih dari 40 tahun dan insidennya bertambah sesuai dengan pertambahan usia. ${ }^{1,49}$ Karakteristik subyek menurut jenis kelamin laki-laki lebih banyak (73,3\%) daripada perempuan $(26,7 \%)$ dengan perbandingan $2,7: 1$. Hasil ini sesuai dengan Munir yang menyatakan bahwa prevalensi laki-laki lebih besar daripada perempuan untuk terkena kanker. ${ }^{49}$ Hal ini disebabkan karena salah satu faktor risiko penyebab KKL adalah merokok sigaret ataupun alkohol yang lebih sering dilakukan oleh lakilaki. ${ }^{1}$ Distribusi jenis keganasan menunjukkan bahwa jenis keganasan terbanyak adalah karsinoma nasofaring $19(63,3 \%)$ kasus yang merupakan keganasan tersering di daerah kepala leher. ${ }^{1,5}$ Stadium penyakit pada penelitian ini pada umumnya sudah lanjut yaitu stadium 3 dan 4 dengan persentase hampir sama besarnya. Subyek lebih banyak pada stadium 4 (53,5\%). Hal ini disebabkan karena pada umumnya penderita KKL akan datang berobat bila gejala sudah sangat mengganggu aktivitasnya sehari-hari, masalah biaya pengobatan dan faktor pengetahuan penyakit yang rendah. ${ }^{1,49}$

Seluruh subyek dalam penelitian ini merupakan pasien KKL yang telah mendapat kemoterapi sebelumnya dan tidak mendapat kemoterapi saat menjalani terapi radiasi. CRP tidak dapat dibedakan 
antara pasien yang menerima radioterapi konkuren dan radioterapi saja dan pada kenyataannya, nilai ambang CRP secara signifikan lebih tinggi pada pasien yang menerima radioterapi konkuren dibanding radioterapi saja, yang menunjukkan penyakit tahap lanjut. ${ }^{9}$

\section{Perubahan Kadar CRP Kelompok Metilprednisolon dan Kontrol Minggu I}

Hasil penelitian terhadap kadar CRP sebelum dan setelah 7 kali radioterapi pada kelompok metilprednisolon dan kontrol menunjukkan peningkatan bermakna kadar CRP $(p<0,05)$ (tabel 2). Hasil analisis perbandingan kelompok metilprednisolon dan kontrol menunjukkan bahwa peningkatan kadar CRP antara kedua kelompok tidak berbeda bermakna $(p>0,05)$. Hasil ini menunjukkan bahwa telah terjadi peningkatan respon inflamasi pada subyek KKL yang mendapat 7 kali radioterapi baik pada kelompok metilprednisolon maupun kontrol.

Radiasi ionisasi dinyatakan sebagai sinyal pro inflamasi, dan respon jaringan normal terhadap paparan radiasi bersifat segera dan membaik seiring dengan waktu. Respon inflamasi yang diinduksi radiasi diinisiasi oleh produksi oksigen reaktif/nitrat, induksi apoptosis dan kematian sel, kerusakan mukosa dan aktivasi transkripsi beberapa sitokin inflamasi dan faktor pertumbuhan pada kompartemen mikrovaskular dan mukosa. ${ }^{31,32}$ Beberapa penelitian menunjukkan mediator pro inflamasi pasca radioterapi mengalami peningkatan yaitu CRP, IL-6 dan IL-1b., ${ }^{96}$ CRP memiliki beberapa fungsi imunitas yang terkait di antaranya opsonisasi (fagositosis) dan aktivasi ikatan komplemen klasik.

Ki melaporkan kadar CRP dan ESR pada pasien KKL yang diterapi dengan Intensed Modulated Radiation Therapy (IMRT) menunjukkan korelasi statistik signifikan antara peningkatan kadar CRP dan dosis radiasi sebagaimana korelasi pada skoring toksisitas NCIC-CTC versi 2.0. Nilai mean kadar CRP meningkat signifikan selama pemberian radioterapi. ${ }^{9}$ Cengiz juga melaporkan peningkatan CRP dan ESR pada akhir terapi radiasi. ${ }^{39}$ Level CRP menunjukkan peningkatan signifikan setelah 15 fraksi radioterapi. Hal ini dapat bervariasi bergantung pada status inflamasi pasien. Nilai mean CRP meningkat signifikan selama pemberian radioterapi fraksinasi dan menurun setelah pemberian radioterapi $(p<0.001) .{ }^{9}$

Pemberian radioterapi pada minggu I (setelah 7 kali radioterapi) menunjukkan peningkatan CRP pada penelitian ini bila dibandingkan dengan penelitian sebelumnya dimana peningkatan CRP signifikan terjadi setelah 15 fraksi radioterapi. Perbedaan peningkatan kadar CRP ini dapat disebabkan penggunaan alat fraksinasi radioterapi yang berbeda pada kedua penelitian. Penelitian ini menggunakan teknik konformal konvensional sedangkan pada penelitian Ki dan Cengiz, keduanya menggunakan IMRT dengan dosis objektif spesifik untuk mempertahankan mukosa normal dimana dapat meminimalisasi reaksi inflamasi mukosa bila dibandingkan dengan teknik konformal konvensional., ${ }^{9,39}$

\section{Perubahan Kadar CRP Kelompok Metilprednisolon dan Kontrol Minggu II}

Hasil penelitian perubahan kadar CRP kelompok metilprednisolon setelah mendapat $7 \mathrm{kali}$ radioterapi dan dilanjutkan hingga 14 kali dengan penambahan pemberian tablet metil prednisolon oral menunjukkan peningkatan kadar CRP namun peningkatan ini tidak bermakna $(p>0,05)$. Hasil penelitian perubahan kadar CRP kelompok kontrol setelah mendapat 7 dan 14 kali radioterapi tanpa pemberian tablet metil prednisolon oral menunjukkan peningkatan bermakna kadar CRP $(p>0,05)$. Hasil analisis perubahan kadar CRP (delta CRP) antara kelompok metilprednisolon dan kontrol menunjukkan perubahan kadar CRP yang bermakna antara kedua kelompok $(p<0,05)$. Hasil ini menunjukkan bahwa pemberian tablet metil prednisolon oral dapat menurunkan peningkatan kadar CRP pada subyek KKL yang mendapat radioterapi.

Glukokortikoid, seperti turunannya dexametason, prednisone dan metil prednisolon, sebagai inflamasi, melalui inhibisi nuclear factor kappa (NF-kB). Efek fisiologis dimediasi melalui inhibisi NF-kB. Dua teori yang diajukan tentang inhibisi glukokortikoid terhadap NF-kB. yaitu, inhibisi transkripsi kB dependen dengan berinteraksi langsung dengan nuclear factor kappa (NF-kB) subunit ReIA dan mempengaruhi potensial serta glukokortikoid telah menunjukkan aktifitas memacu produksi IkBa, menyebabkan inhibisi nyata pada nuclear faktor kappa. Selain itu, glukokortikoid telah menunjukkan inhibisi terhadap trakskripsi dependen kB dengan berinteraksi secara langsung dengan sub unit NFkB ReiA dan mempengaruhi transaktifasi secara potensial. $^{43}$

Aktifitas dan ekspresi NF-kB memicu respon imun berikutnya, dimana pada akhirnya memicu ekspresi IL-1, TNF, IL-6 dan sitokin pro inflamasi lainnya. ${ }^{44}$ Glukokortikoid sebagai anti inflamasi berperan pada pengurangan produksi sitokin pro inflamasi (TNF alfa, IL-ibeta, IL-6), meningkatkan sintesis sitokin anti inlamasi (IL-10, IL-Ira), menurunkan ekspresi molekul adhesi, menghambat sintesis kemokin, phospholipase A2, cyclooxygenase 2 dan sintesis nitrit oksida. ${ }^{42}$ CRP diregulasi oleh sitokin proinflamasi seperti interleukin (IL) 1, tumor necrotic factor (TNF) a, dan terutama interleukin 6 (IL-6). ${ }^{23}$ Pada lingkungan mikro tumor, selsel inflamasi memproduksi sitokin, terutama IL-6 sebagai respon sel tumor, jaringan nekrotik dan inflamasi terkait. Sitokin dikeluarkan ke sirkulasi dan menginduksi hepatosit untuk mensintesis CRP dan protein fase akut lainnya. Setelah kembali dari lingkungan mikro tumor melalui sirkulasi, CRP akan bekerja pada sel tumor. CRP berikatan dengan fosfolipid pada sel tumor dan 
bertindak sebagai opsonin, memicu lisis sel tumor. Di sisi lain, ekspresi COX-2 yang berlebihan memproduksi prostaglandin untuk memfasilitasi progresi tumor, sebagai respon stimuli inflamasi. ${ }^{7}{ }^{25}$ Hasil penelitian ini sesuai dengan penelitian sebelumnya yang dilakukan Dernellis dan Nurhudin dimana keduanya melaporkan mengenai efektifitas pemberian metil prednisolon terhadap kadar CRP. Penelitian yang dilakukan oleh Dernellis tentang efektifitas metilprednisolon oral terhadap CRP pada pasien dengan Atrial Fibrilation (AF) menunjukkan penurunan level CRP plasma dan secara signifikan mencegah rekurensi AF. Hasil ini sesuai dengan yang diharapkan dimana glukokortikoid mengurangi konsentrasi CRP dengan efek anti inflamasi. Pada penelitian ini diberikan dosis metil prednisolon sebesar $16 \mathrm{mg}$ selama 4 minggu dan didapatkan hasil penurunan kadar CRP yang signifikan dimulai minggu pertama dan penurunan kadar CRP bertahan hingga akhir pengamatan. ${ }^{14}$ Penelitian lain dilakukan Nurhudin tentang pemberian metil prednisolon injeksi terhadap kadar CRP pada pasien gagal ginjal yang mengalami hemodialisis juga menunjukkan penurunan signifikan. Pada penelitian ini menggunakan metilprednisolon dosis rendah $(60 \mathrm{mg})$ pada pasien yang akan menjalani hemodialisa dan didapatkan penurunan kadar CRP signifikan paska hemodialisa. ${ }^{13}$

Analisis derajat mukositis didapatkan hasil homogen pada kelompok sebelum dan setelah menjalani 7 kali radioterapi. Analisis derajat mukositis didapatkan perbedaan signifikan pada kelompok dengan 14 kali radioterapi antara kelompok metilprednisolon dan kontrol. Hal ini dimungkinkan karena pada kelompok metilprednisolon subyek diberikan metilprednisolon tablet dimana dapat menurunkan kadar CRP sesuai hasil pembahasan sebelumnya. Studi yang dilakukan Ki menyatakan bahwa peningkatan atau penurunan tingkat keparahan mukositis, nilai mean kadar CRP berubah secara simultan. ${ }^{9}$

\section{SIMPULAN}

Pemberian metil prednisolon oral dapat menurunkan kadar CRP pada penderita KKL yang mendapat radioterapi. Disarankan untuk penelitian lebih lanjut mengenai penggunaan metilprednisolon oral dan pemantauan kadar CRP selama radioterapi pada penderita KKL.

\section{DAFTAR PUSTAKA}

1. Franzmann E, Lilly S, Huang D, Thomas G. Oncology of head and neck tumors. In: Water $\mathrm{T}$, Staecker, editors. Otolaryngology : Basic Science and Clinical Review New York Thieme; 2006.

2. Williyanto O. Insidensi kanker kepala dan leher berdasarkan diagnosis patologi anatomi di RSUP Dr. Kariadi Semarang periode1 Januari-31 Desember 2005. 2006.
3. Kruse AL, Luebbers HT, Gratz KW. C-reactive protein levels: a prognostic marker for patients with head and neck cancer. Head and neck oncology. 2010:2:21.

4. Yunika K. C-reactive protein ( $h s-C R P)$ pada penderita keganasan kepala leher dan faktor-faktor resiko yang berpengaruh Research Article. 2013.

5. Jiang C, Li J, Ao F, Qiu Y, Liao Y. Relationship between Creactive protein and clinical stage in nasopharyngeal carcinoma. Chinese-German Journal of Clinical Oncoloy. 2009;9:2.

6. Hussey DH, Wen BC. Principles of radiation oncology. In: Bailey BJ, Calhoun KH, editors. Head and Neck Surgery Otolaryngology. 4th Edition ed. Philadelphia: Lippincot Williams \& Wilkins; 2006. p. 1389-400.

7. Francois A, Milliat F, Guipad O, Benderitter M. Inflammation and immunity in radiation damage to the gut mucosa. Biomed Research Journal. 2013:1-9. Epub 18 Februari 2013.

8. Vermiere S, Assche GV, Ruggeerts P. C-reactive protein as a marker for inflammatory bowel disease. Inflamm Bowel Dis Jour. 2004;10(5):661-5.

9. Ki Y, Kim W, Nam J, Kim D, Park D, Kim D. C-reactive protein levels and radiation induced mucositis in patients with head and neck cancer. Int J Radiation Oncology Biol. 2009;75:393-8.

10. Kartikawati H. Pengaruh itrakonazol untuk pencegahan mukositis oral akibat efek samping radioterapi pada pasien kanker nasofaring. Oncology. 2009.

11. Fazilat FM, Ian P, Liying Z, Liz E, Ian D. Acute-phase response reactans as objective biomarkers of radiation-induced mucositis in head and neck cancer. Head and Neck oncology. 2011. Epub 26 September 2011.

12. Koc M, Taysi S, Sezen O, Bakan N. Level of some acute phase protein in the serum of patients with cancer during radiotherapy. Biol Pharma Bull. 2003;26(10):1494-7.

13. Nurhuddin A. Pengaruh metilprednisolon dosis rendah terhadap kadar hs CRP dan C3 pada pasien gagal ginjal kronis stadium V pasca hemodialisis. . Research Article. 2010 (Thesis UNS):1-74.

14. Meduri UG, Golden E. Methylprednisolone infusion in early severe Acute Respiratory Distress Syndrome. CHEST. 2007;131:954-63.

15. Dernellis J, Panaretau M. Relationship between c-reactive protein concentrasions during glucocorticoid therapy and recurrent atrial fibrillation. European Heart Journal. 2004;25:1100-7.

16. Edge S, Byrd DR, Compton CC, Fritz AG, Greene FL, Trotti A, et al. AJCC Cancer Staging Manual. 7 th ed: Springer; 2010.649 p.

17. Allin KH, Nordestgaard BG. Elevated c-reactive protein in the diagnosis, prognosis and cause of cancer. Critical reviews in clinical laboratory sciences. 2011;48(4):155-70.

18. Abbas AK, Lichtman AH, Pber JS. Immunity to tumors. In: Co WS, editor. Cellular and molecular immunology.4th ed. Philadelphia2000. p. 382-403.

19. Zamai L, Ponti C, Mirandola P, Gobbi G, Vitale M, Papa S, et al. NK Cells and Cancer. Journal of Immunology. 2007;178:4011-6.

20. Zhou L, Chong MMW, Littman DR. Immunity. Journal of Immunology. 2009;30:646-55.

21. Mosser DM, Edwards JP. Inflammation in cancer. Nat Rev Immunol. 2008;8(12):958-69.

22. Mark J, Smyth, Hayakawa Y, Takeda K, Yagita H. New aspect of natural killer cell. Surveillance and therapy of cancer. 2002;2:850-61. Epub November 2002.

23. Kushner I, Rzewnicki D, Damols D. What does minor elevation of C-reactive protein signify. Am J Med. 2006;119:166.e17-28.

24. Rifai N, Ridker PM. Population distribution of C-reactive protein in apparently healthy men and women in the United States: Implication for clinical interpretation. Clin Chem. 
2003;49:666-9.

25. Mantovani A, Garlanda C, Doni A, Botazzi B. Pentraxin in innate imunity: from $C$-reactive protein to the long pentraxin PTX3. J Clin Immunol. 2008;28:1-3.

26. Roberts WL, Moulton L, Law TC, Farrow G, Cooper-Anderson M, Savory J. Evaluation of nine automated high-sensitivity C-reactive protein methode: Implication for clinical and epidemiological applications. Clin Cem. 2001;47:418-25.

27. McMillan DC, Canna K, McArdle CS. Systemic inflammatory response predicts survival following curative resection of colorectal cancer. Br J Surg. 2003;90:215-9.

28. Helzisoner KJ, Erlinger TP, Platz EA. C-reactive protein levels and subsequent cancer outcomes: result from a prospective cohort studi. Eur J Cancer. 2006;42:704-7.

29. Zeng YC, Xiao YP, Chi F, Wang NQ, Xue M, Zhang XY, et al. C reactive protein levels and $5-\mathrm{Fu}$ induced oral mucositis in colorectal cancer patients chemotherapy with 5-fluorouracil based regimens. Eur J Oncol. 2012;17(2):87-92.

30. Péus D, Newcomb N, Hofer S. Appraisal of the Karnofsky Performance Status and proposal of a simple algorithmic system for its evaluation. BMC Med Inform Decis Mak. 2013;13:72.

31. Ong ZY, Gibson RJ, Bowen JM. Pro-inflammatory cytokines play a key role in the development of radiotherapy-induced gastrointestinal mucositis. Radiation Oncology. 2010;5(1).

32. Milliat F, François A, Tamarat R, Benderitter M. Role of endothelium in radiation-induced normal tissue damages. Annales de Cardiologie et d'Angeiologie. 2008;57(3):139-48.

33. Wang J, Boerma M, Fu Q, Hauer-Jensen M. Significance of endothelial dysfunction in the pathogenesis of early and delayed radiation enteropathy. World Journal of Gastroenterology, . 2007;13(22):3047-55.

34. Blirando K, Milliat F, Martelly I, Sabourin JC, Benderitter M, François A. Mast cells are an essential component of human radiation proctitis and contribute to experimental colorectal damage in mice. American Journal of Pathology. 2011;178(2):640-51.

35. Erlinger TP, Platz EA, Rifai NN, Helzlsouer KJ. C-reactive protein and the risk of colorectal cancer. JAMA. 2009:291.

36. Sonis ST. A multiple mechanism model of the pathobiology of mucositis. JSupport Oncol 2007;5(4):21-32.
37. Pierce BL, Barbash RB, Baumgartner RN. Elevated biomarkers of inflammation are associated with reduced survival among breast cancer patients. American Society of Clinical Oncology. 2009;27:3437-44.

38. Trotti A, Byhardt R, Stetz J. Common toxicity criteria:Version 2.0. An improved reference for grading the acute effects of cancer treatment:Impact on radiotherapy. Int J Radiat Oncol Biol Phys. 2000(47):13-47.

39. Cengiz M, Akbulut S, Atahan IL, Grigsby PW. Acute phase response during radiotherapy. Int J Radiat Oncol Biol Phys. 2001;49:1093-6.

40. Pfizer I. Methylprednisolone tablets : clinical overview to support care. Data Sheet Revisions. 2010:1-16. Epub February 2010.

41. Rhen T, Cidlowski J. Antiinflammatory action of glucocorticoids:new mechanisms for old drugs. $n$ engl $\mathrm{j}$ med. 2005:353. Epub October 20, 2005.

42. Marik PE, Zaloga GP. Adrenal insufficiency in the critically ill: a new look at an old problem. Chest 122. 2002:1784-96.

43. Meduri GU, ArisTolley E, Chrousos GP, Stentz F. Prolonged methylprednisolone treatment suppresses systemic inflammation in patients with unresolving acute respiratory distress syndrome. Am J Respir Crit Care Med 2002;165:983-91.

44. Sorrels S, Sapolsky R. An inflammatory review of glucocorticoid actions in the CNS. Brain Behav Immun. 2007 21(3):259-72. Epub March 2007.

45. Farokhnia F, Arbabi S. Effects of oral methylprednisolone and inhaled salbutamol in the decrease of wheezing in patients with asthma after tracheal intubation. DARU. 2008;16(3):164-9. Epub 24 November 2008.

46. Cooper MS, Stewart PM. Corticosteroid insufficiency in acutely ill patients. N Engl J Med 2003;348(8). Epub Februari 2003.

47. Pfizer I. Medrol. In: Pfizer, editor. Aucland New Zealand2013.

48. Metz LM, Sabuda D, Hilsden RJ, Enns R, Meddings JB. Gastric tolerance of high dose pulse oral prednisone in multiple sclerosis. American Academy of Neurology. 1999;53:2093-6.

49. Munir M. Keganasan di bidang telinga hidung tenggorok. Dalam : Soepardi EA, Iskandar N, Bashiruddin J, Restuti RD, eds. Buku Ajar Ilmu Kesehatan Telinga, Hidung, Tenggorok dan Kepala Leher. Edisi keenam. Jakarta: Balai Penerbit FKUI; 2007:1328. 